Vol. 1 | No. 4 | Oktober 2020 | Hal. 328 - 338

\title{
PERTANIAN ORGANIK SEBAGAI SOLUSI PERTANIAN BERKELANJUTAN DI ERA NEW NORMAL
}

\author{
N. Rachma*, Ahmad Syaekhul Umam \\ Fakultas Ekonomi dan Bisnis, Universitas Islam Malang \\ *Korespondensi email: n.racma_fe@unisma.ac.id
}

\begin{abstract}
ABSTRAK
Keprihatinan petani terhadap lingkungan dan petani bekerja dengan bahan kimia pertanian dalam sistem pertanian konvensional yang mana bahan kimia pertanian membutuhkan proses pembuatan energi intensif yang sangat bergantung pada bahan bakar fosil, maka diperlukan merubah sistem pola pertanian yaitu dengan pertanian organik. Pertanian organik adalah sistem budidaya pertanian yang mengadalkan bahan-bahan alami tanpa menggunakan bahan kimia sintetis. Untuk menyukseskan sosialisasi pertanian organik di desa Dowan kecamatan Gunem kabupaten Rembang, Maka mahasiswa KKN-PPM edisi covid19 kelompok 08 Universitas Islam Malang melakukan sosialisasi dengan cara Door to door. Pertanian organik memberikan dampak dalam pertanian berkelanjutan yang ada di Desa Dowan, baik dampak positif maupun dampak negatif. KKN Tematik Edisi Covid 19 Universitas Islam Malang Kelompok 8 melakukan suatu analisis untuk menjawab tantangan yang selama ini di alami oleh petani. KKN Tematik Edisi Covid 19 Universitas Islam Malang Kelompok 8 melakukan kegiatan sosialisasi untuk menuju pertanian organik dan menjadikan pertanian yang berkelanjutan serta memberikan pelatihan pembuatan pestisida organik sehingga nantinya menjadikan pertanian yang mandiri. Pertanian organik bertujuan untuk mengetahui prinsip dari pertanian organik, mengetahui kelebihan dari pertanian organik dan menyediakan produk-produk pertanian yang aman dikonsumsi dan tidak menimbulkan pencemaran lingkungan. Wawancara digunakan sebagai teknik pengumpulan data untuk menemukan permasalahan dan mengetahui keluhan dari petani yang lebih mendalam. KKN Tematik Edisi Covid 19 Universitas Islam Malang Kelompok 8 melakukan sosialisasi dengan memberikan pengetahuan tentang prinsip pertanian, mensosialisasikan tentang manfaat dari pertanian organik mensosialisasikan dan membantu petani untuk menciptakan produk pestisida organik untuk menuju pertanian berkelanjutan dan edukasi tentang rotasi tanaman sebagai satu penerapan sistem pertanian berkelanjutan.
\end{abstract}

Kata Kunci: pertanian organik; pertanian berkelanjutan.

\section{PENDAHULUAN}

Indonesia dikenal sebagai Negara agraris karena mata pencaharian utama masyarakat Indonesia adalah bercocok tanam. Dan terdapat beraneka ragam pula tanaman pertanian di Indonesia. Namun sangat disayangkan, dewasa ini lahan pertanian Indonesia semakin sempit karena industrialisasi (Sugianto \& Sholihah, 2018). Tanah hijau berubah menjadi tandus dan gersang, bencana alam pun tak dapat dihindari. Selain itu, hal yang juga memprihatinkan adalah pola pikir masyarakat yang masih sering memandang sebelah mata tentang sektor pertanian. Itulah mengapa output pertanian Indonesia tidak sebanding dengan sumber daya alam yang tersedia (Heryawan, Fauzi, \& Hidayat, 2016). Oleh karena itu, diperlukan suatu langkah untuk memajukan pertanian Indonesia yang ramah lingkungan 
sehingga tidak membahayakan makhluk hidup di dalamnya. Salah satu solusi yang tak asing lagi adalah pertanian organic (Candraningsih, 2018). Menurut Mayrowani (2012)Pertanian organik merupakan sistem pertanian yang bersifat ramah lingkungan dan hanya menggunakan bahan-bahan alami tanpa menggunakan bahan-bahan kimia sintetis sehingga menghasilkan produk yang sehat, bergizi dan juga aman dikonsumsi dengan beberapa manfaat diantaranya meningkatkan hasil dalam jangka panjang melalui penggunaan input yang terjangkau, sebagian besar didasarkan pada keanekaragaman hayati lokal, meningkatkan mata pencaharian dan keamanan pangan, membangun ketahanan terhadap perubahan iklim, mengurangi risiko keuangan dengan mengganti input bahan kimia yang mahal dengan sumber daya terbaru yang tersedia secara lokal, mengintegrasikan praktik pertanian tradisional, memungkinkan petani akses ke peluang pasar baru baik di dalam maupun luar negeri, menyediakan ketahanan sistem pertanian pada saat iklim ekstrem seperti kekeringan dan hujan lebat, meningkatkan kesehatan manusia dan memaksimalkan layanan lingkungan, berkontribusi pada mitigasi perubahan iklim, karena mengurangi emisi gas rumah kaca dan menyerap karbon di dalam tanah.

Sejalan dengan hasil penelitian Massijaya (2016) meyatakan bahwa pertanian organik merupakan suatu sistem dalam arti budidaya pertanian yang menggunakan bahan alami tanpa bahan kimia selama proses produksinya. Di dalam pertanian organik dikenal istilah hukum pengembalian atau low of return memiliki arti bahwa suatu sistem yang berusaha untuk mengembalikan semua jenis bahan organik kedalam tanah baik dalam bentuk residu dan limbah pertanaman maupun ternak yang selanjutnya memiliki tujuan memberikan nutrisi untuk tanaman. Prinsip-prinsip tersebut menyangkut bagaimana manusia berhubungan dengan lingkungan hidup, berhubungan satu sama lain dan menentukan warisan untuk generasi mendatang (Suwantoro, 2008). Pertanian organik didasarkan pada:

1. Prinsip Kesehatan

Pertanian organik harus melestarikan dan meningkatkan kesehatan tanah, tanaman, hewan, manusia dan bumi sebagai satu kesatuan dan tak terpisahkan. Prinsip ini menunjukkan bahwa kesehatan tiap individu dan komunitas tak dapat dipisahkan dari kesehatan ekosistem; tanah yang sehat akan menghasilkan tanaman sehat yang dapat mendukung kesehatan hewan dan manusia.

2. Prinsip Ekologi

Pertanian organik harus didasarkan pada sistem dan siklus ekologi kehidupan. Bekerja, meniru dan berusaha memelihara sistem dan siklus ekologi kehidupan. Prinsip ekologi meletakkan pertanian organik dalam sistem ekologi kehidupan. Prinsip ini menyatakan bahwa produksi didasarkan pada proses dan daur ulang ekologis. Makanan dan kesejahteraan diperoleh melalui ekologi suatu lingkungan produksi yang khusus; sebagai contoh, tanaman membutuhkan tanah yang subur, hewan membutuhkan ekosistem peternakan, ikan dan organisme laut membutuhkan lingkungan perairan. Budidaya pertanian, peternakan dan pemanenan produk liar organik haruslah sesuai dengan siklus dan keseimbangan ekologi di alam. Siklus-siklus ini bersifat universal tetapi pengoperasiannya bersifat spesifik-lokal. Pengelolaan organik harus disesuaikan dengan kondisi, ekologi, budaya dan skala lokal. Bahan-bahan asupan sebaiknya dikurangi dengan cara dipakai kembali, didaur ulang dan dengan pengelolaan bahanbahan dan energi secara efisien guna memelihara, meningkatkan kualitas dan melindungi sumber daya alam.

Prinsip-prinsip pertanian organik menurut Yuriansyah, Dulbari, Sutrisno, \& Maksum (2020) prinsip-prinsip pertanian organik adalah: (1) Prinsip kesehatan: pertanian organik harus melestarikan dan meningkatkan kesehatan tanah, tanaman, hewan, manusia dan bumi 
sebagai satu kesatuan dan tak terpisahkan; (2) Prinsip ekologi: Pertanian organik harus didasarkan pada sistem dan siklus ekologi kehidupan. Bekerja, meniru dan berusaha memelihara sistem dan siklus ekologi kehidupan. Prinsip ekologi meletakkan pertanian organik dalam sistem ekologi kehidupan, yang bahwa produksi didasarkan pada proses dan daur ulang ekologis. Siklussiklus ini bersifat universal tetapi pengoperasiannya bersifat spesifik-lokal; (3) Prinsip keadilan: Pertanian organik harus membangun hubungan yang mampu menjamin keadilan terkait dengan lingkungan dan kesempatan hidup bersama; dan (4) Prinsip perlindungan: Pertanian organik harus dikelola secara hati-hati dan bertanggung jawab untuk melindungi kesehatan dan kesejahteraan generasi sekarang dan mendatang serta lingkungan hidup.

Menurut Charina, Kusumo, Sadeli, \& Deliana (2018) sistem pertanian organik mempunyai tujuh kenggulan dan keutamaan sebagai berikut:

1. Orisinil. Sistem pertanian organik lebih mengandalkan keaslian atau orisinalitas sistem budidaya tanaman atau hewan dengan menghindari rekayasa genetika ataupun introduksi teknoloi yang tidak selaras alam. Intervensi budidaya manusia tehadap tanaman atau hewan tetap mengikuti kaidah-kaidah alamiah yang selaras, serasi, dan seimbang.

2. Rasional. Sistem pertanian organik berbasis rasionalitas bahwa hukum keseimbanagan alamiah adalah ciptaan Tuhan yang paling sempurna. Nilai-nilai rasionalitas harus digunakan secara seimbang dengan sistem nilai agama, etika, estetika, yang menempatkan manusia sebagai makhluk mulia.

3. Global. Saat ini, sistem pertanian organik menjadi isu global dan mendapatkan respon serius dikalanagaan masyarakat pertanian, terutama di negara-negara maju dimana masyarakat sudah sangat sadar bahwa pertanian ramah lingkungan menjadi faktor penentu kesehatan manusia dan kesinambungan lingkungan.

4. Aman. Sistem pertanian organik menempatkan keamanan produk pertanian, baik bagi kesehatan manusia ataupun bagi lingkungan, sebagai pertimbangan utama.

5. Netral. Sistem pertanian organik tidak menciptakan ketergantungan atau bersifat netral sehingga tidak memihak pada salah satu bagian ataupun pelaku dalam sistem agroekosistem.

6. Internal. Sistem pertanian organik selalu berupaya mendayagunakan potensi sumber daya alam internal secara intensif. Artinya, introduksi input- input pertanaian dari luar ekosistem pertanian sedapat mungkin dihindari untuk mengurangi terjadinya disharmoni siklus agroekosistem yang sudah berlangsung lama dan terkendali.

7. Kontinuitas. Sistem pertanian organik tidak berorientasi jangka pendek, tetapi lebih pada pertimbangan jangka panjang untuk menjamin keberlangsungan jutaan kehidupan, baik untuk generasi sekarang ataupun yang akan datang.

Pertanian organik dapat digunakan sebagai solusi pertanian berkelanjutan. Pertanian berkelanjutan (Sustainable agriculture) adalah pemanfaatan sumber daya yang dapat diperbaharui (renewable resources) dan sumber daya yang tidak dapat diperbaharui (unrenewable resources) untuk proses produksi pertanian dengan menekan dampak negative terhadap lingkungan seminimal mungkin. Keberlanjutan yang dimaksud meliputi: penggunaan sumberdaya, kualitas dan kuantitas produksi, serta lingkungannya. Proses produksi pertanian yng berkelanjutan akan lebih mengarah pada penggunaan produk hayati yang ramah terhadap lingkungan.

Pada saat pandemi Covid 19 Ketahanan pangan menjadi salah satu hal yang penting karena dapat mengakibatkan berbagai permasalahan di antaranya terganggunya produksi, distribusi, dan konsumsi kebutuhan pokok akibat diberlakukannya pembatasan sosial berskala besar dan larangan perjalanan bagi masyarakat. Kondisi ini dapat memicu 
kekhawatiran jika Indonesia akan mengalami krisis pangan. Hal ini dikuatkan dengan pendapat Organisasi Pangan Dunia atau Food and Agriculture Organization (FAO) yang menyampaikan akan adanya ancaman kelangkaan pangan di masa pandemi Covid 19.

Dalam rangka menjamin ketahanan pangan di masa pandemi Covid 19 di Indonesia, Pemerintah telah menyiapkan berbagai strategi seperti memantau stabilitas harga kebutuhan pokok agar tidak meroket dan meningkatkan produksi pangan nasional berbasis pertanian rakyat serta keberpihakan kepada petani kecil. Untuk mewujudkan hal ini Pemerintah melakukan realokasi anggaran yang lebih besar untuk dialokasikan pada bantuan benih/bibit, program padat karya, stabilisasi stok dan harga pangan, dan distribusi dan transportasi pangan.

Selain itu upaya lain yang dilakukan oleh Pemerintah dalam rangka menjamin ketahanan pangan yaitu memberlakukan new normal. New normal merupakan langkah yang diambil Pemerintah untuk memulihkan kehidupan sosial dan ekonomi. Penerapan new normal yang dilakukan oleh Pemerintah merujuk pada indikator yang dikeluarkan oleh World Health Organization (WHO) dengan beberapa penyesuaian berdasarkan kebutuhan Pemerintah.

Keberadaan Perguruan Tinggi menjadi sangat penting dalam pencapaian pembangunan pertanian di Indonesia karena perguruan tinggi dapat memberikan pandangan, pemikiran, dan masukan terhadap strategi kebijakan yang akan diambil oleh Pemerintah serta menciptakan inovasi yang mampu menjamin ketersediaan pangan di era new normal pandemi Covid 19, seperti halnya Universitas Islam Malang yang melaksanakan KKN Tematik Edisi Covid 19.

Dalam menjalakan kegiatan sosialisasi pertanian organik KKN Tematik Edisi Covid 19 Universitas Islam Malang Kelompok 8 selalu memperhatikan kondisi petani terlebih dahulu, selalu memperhatikan protokol kesehatan, cuci tangan maupun jaga jarak agar memutus penyebaran mikroba kepada orang lain disekitarnya. Kesehatan menjadi salah satu masalah penting dalam dunia pertanian. Dengan demikianlah maksud adanya pertanian organik ini tak lain karena bentuk kepedulian kepada masyarakat terutama terkait penggunaan bahanbahan kimia dalam berbagai jenis lahan pertanian yang berdampak sangat membahayakan.

Program kerja KKN Tematik Edisi Covid 19 Universitas Islam Malang Kelompok 8 adalah mewujudkan kepedulian terhadap Desa Dowan Kecamatan Gunem kabupaten Rembang. KKN Tematik Edisi Covid 19 Universitas Islam Malang Kelompok 8 akan melakukan sosialisasi tentang pentingnya menerapkan pertanian organik di era sekarang demi keberlanjutan dalam bertani. Pertanian berkelanjutan (Sustainable agriculture) adalah pemanfaatan sumber daya yang dapat diperbaharui (renewable resources) dan sumber daya yang tidak dapat diperbaharui (unrenewable resources) untuk proses produksi pertanian dengan menekan dampak negative terhadap lingkungan seminimal mungkin. Keberlanjutan yang dimaksud meliputi: penggunaan sumberdaya, kualitas dan kuantitas produksi, serta lingkungannya. Proses produksi pertanian yng berkelanjutan akan lebih mengarah pada penggunaan produk hayati yang ramah terhadap lingkungan.

Hasil survey di desa Dowan, Selama beberapa hari melaksanakan program kerja kelompok 08, kami perhatikan hampir $80 \%$ petani desa Dowan kurang pengetahuan tentang pertanian organik yang disebabkan beberapa hal ,ada beberapa faktor yang menjadi penyebab kurangnya pengetahuan yaitu kurangnya sosialisasi pertanian organik yang digalakan oleh pemerintah desa yang mengakibatkan petani masih berpegang teguh kepetani pestisida kimia.Oleh sebab itu KKN Tematik Edisi Covid 19 Universitas Islam Malang Kelompok 8, tertarik untuk mengambil tema pertanian Organik Sebagai Solusi Pertanian Berkelanjutan Di Era New Normal di Desa Dowan, Rembang, Jawa Tengah. 
Dari uraian diatas maka dapat dirumuskan masalah yaitu Bagaimana Pertanian Organik Sebagai Solusi Pertanian Berkelanjutan Di Era New Normal di Desa Dowan? Dengan Tujuan untuk menerapkan Tanaman Organik Sebagai Solusi Pertanian Berkelanjutan Di Era New Normal di Desa Dowan. KKN Tematik Edisi Covid 19 Universitas Islam Malang Kelompok 8 dengan kegiatan sosialisasi menuju pertanian organik yang berkelanjutan yang dilaksanakan selama 1 bulan, dimulai sejak 03 Agustus-03 September 2020, yang bertempat di Desa Dowan, Kecamatan Gunem, Kabupaten Rembang Jawa Tengah. Adapun sasaran yang menjadi objek sekaligus subyek kegiatan sosialisasi pertanian organik yaitu masyarakat pada umumya dan petani desa dowan pada khususnya. Program sosialisasi pertanian organik dilaksanakan pukul 18.00 -19.00 di Rumah masing-masing petani Desa dowan dan dilakukan selama 4 hari.

\section{METODE}

KKN Tematik Edisi Covid 19 Universitas Islam Malang Kelompok 8 yang berjudul "Pertanian Organik Sebagai Solusi Pertanian Berkelanjutan Di Era New Normal" ini menggunakan beberapa tahapan. Pada tahapan identifikasi permasalahan di lapangan menggunakan metode wawancara. Wawancara digunakan sebagai teknik pengumpulan data untuk menemukan permasalahan dan mengetahui hal-hal dari responden yang lebih mendalam.

Proses identifikasi masalah dapat dilakukan dengan mendeteksi permasalahan sosial yang diamati kemudian mengambil langkah untuk mengetahui lebih lanjut, bisa dengan melakukan survey awal. Lokasi KKN Tematik Edisi Covid 19 Universitas Islam Malang Kelompok 8, di desa Dowan, Kecamatan Gunem, Kabupaten Rembang. Alasan memilih tempat tersebut yaitu selain untuk mengembangkan desa Dowan di bidang pertanian juga ada bagian yang sangat berpotensi yang ahrus dikembangkan dan untuk mencegah terjadinya penyebaran covid 19. waktu pelaksanaan KKN ini dilakukan pada tanggal 3 Agustus 2020 s/d 3 September 2020.Responden adalah semua orang baik secara individu maupun kolektif yang akan dimintai keterangan yang diperlukan oleh pencari data. Kemampuan responden sedikit banyak mempengaruhi jawaban atau informasi yang diberikan, terutama kalau pertanyaan menyangkut nama baik daerah atau pernyataan yang bersifat sensitive. Untuk mendapatkan informasi yang baik tentunya kita harus mengetahui waktu luang yang dimiliki petani guna memperoleh informasi yang sempurna.

\section{HASIL DAN PEMBAHASAN}

Pertanian organik adalah sistem budidaya pertanian yang mengandalkan bahanbahan alami tanpa menggunakan bahan kimia sintetis. Pertanian organik merupakan kegiatan bercocok tanam yang ramah atau akrab dengan lingkungan dengan cara berusaha meminimalkan dampak negatif bagi alam sekitar dengan ciri utama pertanian organik yaitu menggunakan varietas lokal, pupuk, dan pestisida organik dengan tujuan untuk menjaga kelestarian lingkungan. Pertanian organik adalah cara menanam tanaman secara alami dengan penekanan terhadap perlindungan lingkungan dan pelestarian tanah serta sumber air kita yang berkelanjutan. Pertanian organik tidak menggunakan pupuk buatan yang berasal dari bahan bakar minyak, pestisida, atau makanan dari hasil modifikasi genetika. Sedangkan pertanian yang berkelanjutan adalah back to nature, yakni sistem pertanian yang tidak merusak, tidak mengubah, serasi, selaras, dan seimbang dengan lingkungan atau pertanian yang patuh dan tunduk pada kaidah-kaidah alamiah. Upaya manusia yang mengingkari kaidah-kaidah ekosistem dalam jangka pendek mungkin mampu memacu produktivitas lahan dan hasil. Namun, dalam jangka panjang biasanya hanya akan berakhir dengan kehancuran lingkungan. Kita yakin betul bahwa hukum alam adalah kuasa Tuhan. 
Manusia sebagai umat-Nya hanya berwenang menikmati dan berkewajiban menjaga serta melestarikannya.

Dari hasil kegiatan KKN Tematik Edisi Covid 19 Universitas Islam Malang Kelompok 8 Ketahanan pangan sangat tergantung pada kemampuan petani dalam memproduksi jumlah yang banyak dan bagus. Tujuan dari sosialisasi pembuatan pupuk pestisida organik yaitu untuk menciptakan pertanian berkelanjutan dan membantu ekonomi masyarakat petani dalam memenuhi input dengan memanfaatkan bahan yang ada di sekitarnya sehingga akan adanya pengurangan penggunaan pupuk kimia dan beralih menggunakan pupuk pestisida organik sehingga dapat menekan biaya pengeluaran untuk pembelian pupuk, membantu memperbaiki struktur tanah, dan meningkatkan produksi pangan dan ekonomi sehingga meningkatkan taraf pendapatan warga.

Kegiatan sosialisasi pertanian organik yang dilaksanakan oleh KKN Tematik Edisi Covid 19 Universitas Islam Malang Kelompok 8, di Desa Dowan dengan tema "Pertanian Organik Sebagai Solusi Pertanian Berkelanjutan Di Era New" dilakukan melalui beberapa tahapan:

\section{Tahap I Survey Lokasi}

Survey lokasi dilakukan untuk mencari informasi tersendiri dari pertanian desa Dowan dan nantinya mampu melihat potensi dan hambatan dari pertanian di Desa Dowan. Selama beberapa hari melaksanakan program kerja kelompok 08, kami perhatikan hampir $80 \%$ petani desa Dowan kurang pengetahuan tentang pertanian organik yang disebabkan beberapa hal ada beberapa faktor yang menjadi penyebab kurangnya pengetahuan yaitu kurangnya sosialisasi pertanian organik yang digalakan oleh pemerintah desa yang mengakibatkan petani masih berpegang teguh pada pertanian pestisida kimia serta minimnya ilmu serta informasi yang di dapat petani di Desa Dowan.

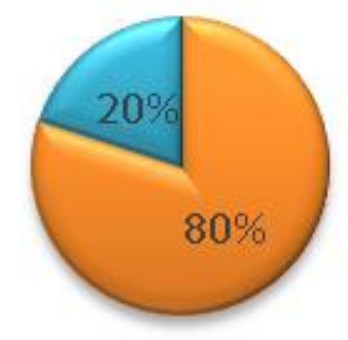

\section{tidak tahu $\square$ sedikit tahu}

Gambar 1. Diagram besaran survey

Dari hasil survey di Desa Dowan terdapat beberapa fakta yang menunjukkan sebagai berikut:

a. Kurangnya pemahaman tentang Prinsip- prinsip pertanian organik

KKN Tematik Edisi Covid 19 Universitas Islam Malang Kelompok 8, di Desa Dowan melakukan survey ke petani. Hasil survey menunjukkan bahwa rata-rata petani desa Dowan:

- mengabaikan prinsip-prinsip pertanian

- mengabaikan masalah kesehatan baik kesehatan jasmani maupun kesehatan lingkungan

- pengetahuan tentang pertanian organik masih minim

b. Kurangnya pengetahun tentang manfaat dari pertanian organik

KKN Tematik Edisi Covid 19 Universitas Islam Malang Kelompok 8, di Desa Dowan melakukan survey ke berbagai petani yang ada. Hasil survey menunjukkan bahwa 
rata-rata petani desa Dowan menggunakan pestisida kimia tanpa mengetahui dampak yang akan di hadapi petani yang akan datang.

\section{c. Pupuk organik masih di gunakan sebagai pupuk pelengkap}

KKN Tematik Edisi Covid 19 Universitas Islam Malang Kelompok 8, di Desa Dowan melakukan survey ke berbagai petani yang ada. Hasil survey menunjukkan bahwa rata-rata petani desa Dowan, masih belum yakin dan percaya bahwa pupuk organik memberikan efek yang lebih bagus daripada pupuk pestisida kimia. Sehingga petani masih berpegang teguh terhadap pestisida kimia dan ragu untuk beralih ke pestisida organik. Penggunaan pupuk anorganik sangat mahal.

\section{d. Kurangnya informasi pertanian organik}

KKN Tematik Edisi Covid 19 Universitas Islam Malang Kelompok 8, di Desa Dowan melakukan survey ke berbagai petani yang ada. Hasil survey menunjukkan bahwa rata-rata petani desa Dowan

- masih kurang informasi tentang pertanian yang lebih maju, dengan demikian perkembangan pertanian yang ada di desa Dowan sangat terhambat dan petani desa Dowan masih bersifat tertutup antara petani satu dengan petani lainya.

- kurangnya perhatian pemerintah desa terhadap perkembangan pertanian di Desa Dowan.

Setelah KKN kelompok 8 Unisma melakukan survey, didukung dengan lahan pertanian yang luas petani desa dowan dan banyak petani yang berminat untuk beralih ke pertanian organik maka petani Desa Dowan sangat berperpotensi untuk di kembangkan ke pertanian organik. Berdasarkan hasil survey yang ada tersebut maka, KKN Tematik Edisi Covid 19 Universitas Islam Malang Kelompok 8, di desa Dowan dapat mengklasifikasi masalah pada program kerja KKN yang terdapat pada Tabel 1. Berdasarkan klasifikasi pada tabel 1 maka KKN Tematik Edisi Covid 19 Universitas Islam Malang Kelompok 8, di desa Dowan mencoba pemecahan masalah yang dituangkan dalam bentuk kegiatan, melakukan sosialisasi dengan memberikan tentang prinsip pertanian mensosialisasikan tentang manfaat dari pertanian organik , mensosialisasikan dan dan membantu petani untuk menciptakan produk pestisida organik ,memberikan informasi melalui kegiatan sosialisasi, mensosialisasikan tentang manfaat dari pertanian organik berkelanjutan,mensosialisasikan dan dan membantu petani untuk menciptakan produk pestisida organik, memberikan informasi melalui kegiatan sosialisasi pertanian organik. Berbagai kegiatan tersebut diharapkan mampu untuk meyelesaikan masalah yang di hadapi oleh petani di Desa Dowan. Agar kegiatan berjalan lancar maka diperlukan dukungan petani dan dilakukan dengan menyesuaikan waktu yang di berikan oleh petani ketika melaksanakan berbagai serangkaian kegiatan sosialisasi ke petani.

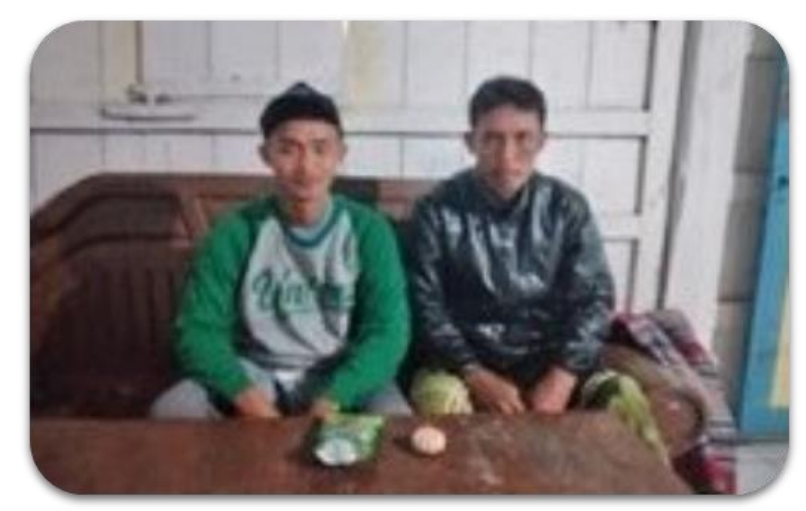

Gambar 1. Proses sosialisasi yang dilakukan disalah satu rumah warga 
Tabel 1. Program KKN

\begin{tabular}{|c|c|c|c|}
\hline No & Masalah & PemecahanMasalah & Bentuk Kegiatan \\
\hline 1. & $\begin{array}{c}\text { Kurangnya } \\
\text { pemahaman } \\
\text { tentang Prinsip- } \\
\text { prinsip pertanian } \\
\text { organik }\end{array}$ & $\begin{array}{l}\text { Memberikan edukasi } \\
\text { pentingnya } \\
\text { penerapan prinsip- } \\
\text { prinsip pertanian }\end{array}$ & $\begin{array}{l}\text { Melakukan sosialisasi dengan memberikan } \\
\text { tentang prinsip pertanian Mensosialisasikan } \\
\text { tentang manfaat dari pertanian organik } \\
\text { Mensosialisasikan dan dan membantu petani } \\
\text { untuk menciptakan produk pestisida organik } \\
\text { Memberikan informasi melalui kegiatan } \\
\text { sosialisasi }\end{array}$ \\
\hline 2. & $\begin{array}{c}\text { Kurangnya } \\
\text { pengetahun tentang } \\
\text { manfaat dari } \\
\text { pertanian organik } \\
\text { berkelanjutan }\end{array}$ & $\begin{array}{c}\text { Memberikan edukasi } \\
\text { manfaat dari } \\
\text { pertanian } \\
\text { berkelanjutan }\end{array}$ & $\begin{array}{c}\text { Mensosialisasikan tentang manfaat dari pertanian } \\
\text { organik berkelanjutan }\end{array}$ \\
\hline 3. & $\begin{array}{c}\text { Pupuk organik } \\
\text { masih di gunakan } \\
\text { sebagai pupuk } \\
\text { pelengkap }\end{array}$ & $\begin{array}{l}\text { Edukasi pentingnya, } \\
\text { potensi dan manfaat } \\
\text { dari pesstisida } \\
\text { organik. }\end{array}$ & $\begin{array}{l}\text { Mensosialisasikan dan dan membantu petani } \\
\text { untuk menciptakan produk pestisida organik }\end{array}$ \\
\hline 4 & $\begin{array}{c}\text { Kurangnya } \\
\text { informasi pertanian } \\
\text { organic }\end{array}$ & $\begin{array}{c}\text { Memberikan } \\
\text { informasi ke petani } \\
\text { tentang pertanian } \\
\text { organic }\end{array}$ & $\begin{array}{l}\text { Memberikan informasi melalui kegiatan } \\
\text { sosialisasi pertanian organik }\end{array}$ \\
\hline
\end{tabular}

\section{Tahap II Mengajukan izin}

Mengajukan izin untuk melakukan sosialisasi pertanian organik ke perangkat Desa Dowan yang dilakukan mahasiswa KKN-PPM Universitas Islam Malang.Adapun sosialisasi kegiatan didasarkan pada hasil survey pada petani Desa Dowan atas permasalahan sebagai berikut:

a. Kurangnya pemahaman tentang Prinsip- prinsip pertanian organik maka KKN Tematik Edisi Covid 19 Universitas Islam Malang Kelompok 8 langsung memberikan pemahaman tentang pentingnya menjalankan pertanian yang ramah lingkungan dengan menerapkan prinsip-prinsip pertanian organic.

b. Kurangnya pengetahun tentang manfaat dari pertanian organik, maka KKN Tematik Edisi Covid 19 Universitas Islam Malang Kelompok 8, di Desa Dowan segera melakukan sosialisasi yaitu dengan:

- Mengenalkan pertanian organik dalam usia produksi ke petani agar secara perlahan nantinya petani desa Dowan mulai beralih ke pertanian organik dan tidak lagi berpacu pada hasil namun berpacu pada manfaat di sekeliling lingkungan pertanian.

- Karena di desa dowan sudah ada 2 petani yang menerapkan pertanian organik dan hasilnya pun juga berbeda dengan pertanian kimia lebih banyak pertanian organic, maka KKN Tematik Edisi Covid 19 Universitas Islam Malang Kelompok 8, di Desa Dowan mengenalkan bahwa pertanian organik sebagai solusi pertanian berkelanjutan. Ciri dari pertanian berkelanjutan yaitu petani mampu menghasilkan keuntungan dalam tingkat produksi yang cukup dan stabil, pada tingkat resiko yang bisa ditolerir/diterima. Kualitas agroekosistem dipelihara atau ditingkatkan, dengan menjaga keseimbangan ekologi serta konservasi keanekaragaman hayati. Sistem pertanian yang berwawasan ekologi adalah sistem yang sehat dan mempunyai ketahanan yang tinggi terhadap tekanan dan gangguan. 
- Edukasi tentang rotasi tanaman merupakan salah satu penerapan sistem pertanian berkelanjutan. Hal ini merupakan metode pergiliran tanaman agar tanaman dapat menyesuaikan dengan lingkungan. Dengan menyesuaikan kondisi di lapangan, maka input pada lahan pertanian dapat diminimalkan sehingga mengurangi adanya residu yang berlebih pada penerapan budidaya secara rotasi.

c. Pupuk organik masih di gunakan sebagai pupuk pelengkap maka KKN Tematik Edisi Covid 19 Universitas Islam Malang Kelompok 8, di desa Dowan memberikan bantuan solusi dengan pembuatan pestisida organik yang nantinya pestisida kimia hanya di jadikan pelengkap. Dengan pertanian organik petani tidak perlu lagi khawatir mengenai pengeluaran biaya pupuk karena petani bisa memanfaatkan sumber hara yang diperoleh dari kotoran hewan ternak, sisa hasil panen ataupun rumput liarPembuatan pestisida organik akan menjadi jawaban tersendiri yang selama ini di keluhkan oleh petani serta menuju pertanian organik yang berkelanjutan, adapun keluhan yang di alami petani antara lain mulai dari berbagai hama yang menyerang, harga pestisida yang mahal dan hama yang sudah ampuh terhadap pestisida kimia. Maka dari itu di bentuk pelatihan pembuatan pestisida organik yang bahannya mudah di dapat yang bahanya terdiri dari bawang putih dan sunlight.

d. Kurangnya informasi pertanian organik maka KKN Tematik Edisi Covid 19 Universitas Islam Malang Kelompok 8, di desa Dowan melakukan sosialisasi betapa pentingnya untuk menerapkan pertanian organik untuk menuju pertanian berkelanjutan, dimana petani desa dowan masih mengabaikan kesehatan jasmani maupun lingkungan dan kealamian hasil produksi dan hanya menekan pada hasilnya saja tanpa memperhatikan efeknya. Tentunya dengan demikian juga memiliki dampak terhadap kesuburan tanah dan kesehatan jasmani.

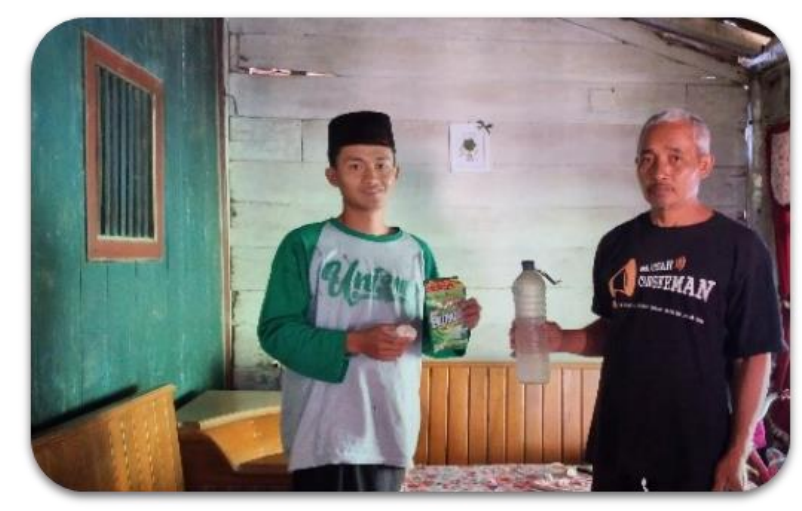

Gambar 2. Pestisida organik

Dengan adanya kegiatan sosialisasi ke petani, tentunya akan menambah wawasan ke petani sendiri dan menjadi wadah tempat menampungnya berbagai keluhan dan nantinya di temukan suatu solusi dari berbagai keluhan yang selama ini di alami oleh petani.

Dengan adanya PSBB yang di terapkan oleh pemerintah sangat mengganggu proses produksi oleh petani, dari pemenuhan input hingga menjual hasil produksi. Dengan demikian mengakibatkan pemasukan petani sangat terhambat yang mengakibatkan produksi selanjutnya yang terganggu. Di desa Dowan petani sudah berfikir bahwasanya Tanaman Organik Solusi Pertanian Berkelanjutan Di Era New Normal sangat cocok untuk di terapkan, bila kesadaran akan pentingnya untuk beralihnya ke pertanian organik, Dengan itu pertanian akan di jamin keberlanjutan 
bertani yang akan mengasilkan produksi produksi yang melimpah dengan memperhatikan kondisi lingkungan yang ada. Adapun Upaya yang dilakukan berupa Stimulus ekonomi dan kemandirian pangan, sangat penting untuk bertahan pada era pandemi Covid 19, serta dengan adanya kemandirian petani dalam memnuhi kebutuhan input petani juga akan menjadi mudah dalam memenuhi kebutuan petani. Dengan demikian Pertanian organik sangat mungkin dilakukan di desa. Jika desa menjalankan pertanian organik maka desa akan memiliki ciri sebagai kawasan organik, kawasan tanpa bahan kimia. Kondisi Desa yang organik ini dapat menjadi desa percontohan dan dapat dijadikan sebagai desa dengan model pertanian organik dan menjadi tempat pembelajaran organik dan mampu membuat obat petisida organik yang ramah lingkungan. Selain itu akan menciptakan hasil produksi yang sehat untuk di konsumsi serta menjadikan hasil pertanian yang lebih berkualitas.

\section{KESIMPULAN}

KKN Tematik Edisi Covid 19 Universitas Islam Malang Kelompok 8, di desa Dowan dengan Tema "Pertanian Organik Sebagai Solusi Pertanian Berkelanjutan Di Era New Normal" mendapatkan sambutan positif dari petani dan masyarakat sekitar desa Dowan, kecamatan Gunem, kabupaten Rembang.

Program yang dilaksanakan adalah melaksanakan sosialisasi, pembuatan pestisida organik ke petani desa Dowan tentang pentingnya menerapkan pertanian organik nerkelanjutan dan sekaligus memberikan jawaban dari permasalahan yang dihadapi banyak petani yang di alami saat ini. Akan tetapi apabila pola pikir SDM (Sumber Daya Manusia) rendah maka akan menghambat Pertanian organik sebagai pertanian yang berkelanjutan.

\section{UCAPAN TERIMA KASIH}

Ucapan terima kasih disampaikan kepada kepala Desa Dowan beserta Perangkat Desa dan Kepala Dusun Dowan yang telah menerima dan membantu mahasiswa peserta KKN-PPM selama 1 bulan dan menjalankan program kerja. Ucapan terima kasih juga disampaikan kepada Panitia KKN-PPM dan Ketua LPPM Universitas Islam Malang yang telah memberikan kesempatan dan memudahkan terlaksananya kegiatan KKN- PPM.

\section{DAFTAR RUJUKAN}

Candraningsih. (2018). Mengembangkan Pertanian Organik untuk Pertanian Indonesia yang Ramah Lingkungan. Website Resmi Pemerintah Kabupaten Bulelelng. Retrieved from https://www.bulelengkab.go.id/detail/artikel/mengembangkan-pertanian-organikuntuk-pertanian-indonesia-yang-ramah-lingkungan-72

Charina, A., Kusumo, R. A. B., Sadeli, A. H., \& Deliana, Y. (2018). Faktor-faktor yang Mempengaruhi Petani dalam Menerapkan Standar Operasional Prosedur (SOP) Sistem Pertanian Organik di Kabupaten Bandung Barat. Jurnal Penyuluhan, 14(1), 6878. https://doi.org/10.25015/penyuluhan.v14i1.16752

Heryawan, A., Fauzi, A., \& Hidayat, A. (2016). Analisis Ekonomi Dan Kebijakan Sumber Daya Alam Provinsi Jawa Barat. Journal of Agriculture, Resource and Environmental Economics, 1(2), 1-11. https://doi.org/10.29244/jaree.v1i2.11757

Massijaya, M. Y. (2016). Pengembangan Pertanian Organik di Indonesia - Pemikiran Guru Besar IPB. (D. A. Astuti, Sudarsono, A. Sulaeman, \& M. Syukur, Eds.) (Vol. 1). Bogor: IPB Press. Retrieved from http://repository.ipb.ac.id/bitstream/handle/123456789/83107/Beras Organik_Prof Sandra\%2Bcover.pdf.pdf 
Mayrowani, H. (2012). Pengembangan Pertanian Organik di Indonesia. Forum Penelitian Agro Ekonomi, 30(2), 91. https://doi.org/10.21082/fae.v30n2.2012.91-108

Sugianto, A., \& Sholihah, A. (2018). Kelompok Petani Jamur Tiram Putih di Desa Blayu, Kecamatan Wajak, Kabupaten Malang. Jurnal Inovasi Hasil Pengabdian Masyarakat (JIPEMAS), 1(2), 129-136. https://doi.org/10.33474/jipemas.v1i2.1517

Suwantoro, A. A. (2008). Analisis pengembangan pertanian organik di Kabupaten Magelang (studi kasus di Kecamatan Sawangan). UNDIP - Tesis. Universitas Diponegoro. Retrieved http://eprints.undip.ac.id/16429/1/Andreas_Avelinus_Suwantoro.pdf

Yuriansyah, Dulbari, Sutrisno, H., \& Maksum, A. (2020). Pertanian Organik sebagai Salah Satu Konsep Pertanian Berkelanjutan. PengabdianMu: Jurnal Ilmiah Pengabdian Kepada Masyarakat, 5(2), 127-132. https://doi.org/10.33084/pengabdianmu.v5i2.1033 